\title{
A közfoglalkoztatás jelentősége Borsod-Abaúj-Zemplén megye rurális településein
}

\section{The significance of public works programmes in rural settlements of Borsod-Abaúj-Zemplén county}

\author{
LIPTÁK KATALIN
}

LIPTÁK Katalin: egyetemi docens, Miskolci Egyetem, Gazdaságtudományi Kar; 3515 Miskolc-Egyetemváros; liptak.katalin@uni-miskolc.hu; https://orcid.org/0000-0001-6714-0858

KULCSSZAVAK: közfoglalkoztatás; települések; Borsod-Abaúj-Zemplén megye

ABSZTRAKT: A munkanélküliség kezelése mind a nemzetközi, mind a hazai közgazdasági és szociológiai szakirodalomban régóta kutatott témakör. A magyarországi periférikus térségekben, településeken, aprófalvakban fokozottan fennálló probléma a magas munkanélküliség és a gyenge humánerőforrás-potenciál. A munkanélküliek számára a központi vagy helyi kormányzat közpénzekből biztosít munkalehetőséget. Ennek bevett formája a segélyezés és a valódi munkavégzés között elhelyezkedő közfoglalkoztatás. A közfoglalkoztatás eredetileg a közösség érdekét szolgáló állami, önkormányzati feladatok, fejlesztések költségeinek munkával való megváltását szolgálta, a gyakorlatban egyes településeken ez lett az egyetlen és tartós foglalkoztatási lehetőség. G. Fekete Éva munkatársaival több kutatásában vizsgálta a közfoglalkoztatást és a vegyes gazdaság irányába való elmozdulási lehetőségeket rurális terekben. E tanulmány célja a Borsod-AbaújZemplén megyében megismételt kérdoíves felmérés eredményeinek bemutatása, az azóta eltelt változások feltárása, elemzése (az első lekérdezésre 2010-ben került sor, az újabb adatfelvételt 2020-ban bonyolítottuk le).

Katalin LIPTÁK: associate professor, Faculty of Economics, University of Miskolc; Egyetemváros, H-3515. Miskolc, Hungary; liptak.katalin@uni-miskolc.hu; https://orcid.org/0000-0001-6714-0858

KEYWORDS: public works programmes; settlements; Borsod-Abaúj-Zemplén county

ABSTRACT: Finding effective and efficient solutions to long-term structural unemployment has been a major challenge for policy-makers worldwide. In Hungary public work programmes that have been funded by the central state but implemented by local governments were first introduced in the late 1980s, and significantly expanded in 2009 and in subsequent years. Started out as activation measures to tackle long-term unemployment in peripheral rural regions, the Hungarian public works scheme has developed a punitive flavour by excluding individuals who fail to enter the public works programme from the social assistance system. This workfare type public works programme eventually evolved into a local development policy tool aiming to strengthen the power of local elites. For people living in small rural settlements, public works have become the only and permanent employment opportunity and it crowded out resources for any other employment or social policies.

Academic research conducted by Éva G. Fekete studied for decades the effects of the public works programme intersecting with mixed economy-type initiatives in rural areas. This study aims to analyse the results of the rehashed survey that G. Fekete conducted in 2010 on the public works programme in Borsod-Abaúj-Zemplén county, in Northern Hungary. The survey repeated in 2020

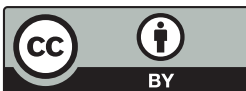


explored changes that have taken place locally as a result of policy changes over the past 10 years. Data shows that the situation of small villages and peripheral settlements has not improved significantly and the most pressing issue for them is still the management of high unemployment levels. Tackling the labour market problems of small villages requires an innovative, novel approach, which can only be achieved in settlements inhabited by young/middle-aged and motivated residents. Domestic employment policy is based on the paradigm of jobs, i.e. the focus is on the classic wage work and the expansion of the number of jobs. Based on global trends, however a long-term imbalance between wage-type jobs and the working-age population is to be expected. The social organizing function of work should be better emphasized in the future and there should be an even greater shift from job-centric to work-centric or income-centric policies. This would be urgent in a rural area, such as the region of Northern Hungary, taking into account that the available labour reserve is limited for development. As suggested by Éva G. Fekete, it is the construction of mixed employment and income generation models that can provide a solution in areas with persistently high unemployment and low entrepreneurial potential.

\section{Bevezetés}

A munkaerőpiac globális átrendeződésével a munkanélküliség súlyos társadalmi problémává vált (Dahrendorf 1994; Castel 1996; Martin-Schumann 1998; Vobruba 2000), amelyen azonban az állam beavatkozása segíthet. Mivel a munkahiány nagyon sok gazdasági, társadalmi baj forrása, kevés olyan fontos közcél van, mint a munkanélküliek számának csökkentése, a jogszerüen foglalkoztatottak számának növelése. A közfoglalkoztatás fő feladata napjainkban a munkaerőpiacról kiszorult egyének kieső jövedelmének valamilyen szintű pótlása, értékteremtő munka végeztetése és a megélhetési bűnözés visszaszorítása (Csoba 2010a). A közfoglalkoztatás gyökerei messzire nyúlnak, hiszen már a középkorban is találkoztunk olyan megoldásokkal, amelyek a mezőgazdaságban a munka nélkül maradottakat igyekeztek segíteni (Csoba 2010b). A közfoglalkoztatás mindig azokban a korszakokban kapott nagyobb hangsúlyt, melyekben a korábbi gazdasági és foglalkoztatási formák éppen átalakulóban voltak, s az átmenet ideje alatt keletkezett munkaerőpiaci kereslet-kínálati egyensúly, valamint az ennek következtében kialakult jövedelemhiány kikényszerítette a központi hatalom beavatkozását. A közfoglalkoztatás egyik funkciója, hogy megerősítse a javak elosztásának szabályát a munkaközpontú rendszerekben, emlékeztessen a közösséghez való tartozással járó kötelezettségekre, s keretet teremtsen a közfeladatok ellátásában való részesedéshez.

A közfoglalkoztatás alkalmazása a válságok idején nem új keletű, hiszen az első nagy világválság után, 1933-ban az Amerikai Egyesült Államokban is országos közfoglalkoztatást vezettek be, és állami megrendelésekre vetették be a felhalmozódott munkaerőt. Az állam a közfoglalkoztatással, vagyis a mesterségesen generált pótlólagos kereslettel tudott hozzájárulni a válság mélységének csökkentéséhez (Szabó 2013). Ahogy Koltai (2013) fogalmaz, a magyar rendszer inkább tipikus válságkezelő gyakorlatnak tekinthető, mintsem egyedülálló példának. 
Magyarországon a mai értelemben vett közfoglalkoztatás a rendszerváltás okozta strukturális nehézségek kezelésére jött létre. A közfoglalkoztatás mint közpolitikai eszköz eredetileg a közösség érdekét szolgáló állami, önkormányzati feladatok, fejlesztések költségeinek munkával való megváltását szolgálta (Koós 2016). A munkanélküliek számára a központi vagy helyi kormányzat közpénzekből biztosíthat - leginkább átmeneti - munkalehetőséget. Ennek bevett formája a segélyezés és a valódi munkavégzés között elhelyezkedő közfoglalkoztatás (G. Fekete et al. 2011), amelyet G. Fekete Éva munkássága során több évtizeden át tanulmányozott, és kutatásokat is vezetett e tárgyban. Ezekben a kutatásokban én is részt vettem, és a téma iránti érdeklődésemet, szemléletemet a közös munka nagy mértékben befolyásolta.

A tanulmány célja, hogy megismételve a G. Fekete Éva által vezetett kutatás keretében 2010-ben készült kérdőíves felmérést, feltárja és elemezze az azóta eltelt változásokat Borsod-Abaúj-Zemplén megye településein. Mivel aktívan részt vettem a 2010. évi kutatásban (annak fóbb eredményeit a későbbi fejezetekben ismertetem), a kérdőívek feldolgozásában, úgy döntöttem, hogy egy ismétlő felmérés méltó emlékezés lehet Éva munkásságára, és talán új eredmények ismertetésére is. Kíváncsi voltam arra, hogy tíz év elteltével a közfoglalkoztatási rendszerben bekövetkezett változások a rurális településeken, aprófalvakban okoztak-e jelentős elmozdulást a munkaerőpiaci problémák kezelésében.

\section{A munkanélküliség kezelése a közgazdasági elméletek szerint}

A közgazdasági elméletek jellemzően három beavatkozási módot ajánlanak a munkaerőpiaci problémák kezelésére.

A foglalkoztatás, a kamat és a pénz általános elmélete címü müvének 18. fejezetét (A foglalkoztatottság általános elméletének újrafogalmazása) Keynes annak a tisztázásával kezdi, hogy a gazdasági rendszer mely elemeit vesszük adottaknak, melyek rendszerünk független és függő változói. „Adottnak vesszük a foglalkoztatható munkaerő meglevő tanultsági fokát és mennyiségét, a felhasználható felszerelés meglevő minőségét és mennyiségét, a meglevő technikát, azt, hogy milyen fokú a verseny, továbbá a fogyasztók ízlését és szokásait, a különböző intenzitással végzett munkával, illetve a felügyeleti és szervező tevékenységgel járó áldozatokat, csakúgy, mint a társadalmi struktúrát, ideszámítva a korábban felsorolt változóink kivételével azokat az erőket, amelyek meghatározzák a nemzeti jövedelem elosztását" (Keynes 1965, 268.). Ez nem jelenti azt, hogy e tényezőket konstansnak feltételezte, hanem csak azt, hogy e helyen és ebben az összefüggésben nem vizsgálta, illetve nem vette számba változásaik hatásait és következményeit. Független változók elsősorban a fogyasztási hajlandóság, a tőke határhatékonyságának a függvénygörbéje és a kamatláb. Függő változók a foglalkoztatás volumene és a nemzeti jövedelem béregységekben mérve. Azok a 
tényezők, amelyeket adottaknak vett, befolyásolják, de nem határozzák meg teljesen a független változókat. John Maynard Keynes ezzel szemben azon az állásponton volt, hogy a teljes foglalkoztatás eléréséhez aktív kormányzati politika szükséges, úgy gondolta, hogy a kereslet gerjesztése révén növelhető a foglalkoztatás és ezzel a gazdasági teljesítmény (Keynes 1965).

Milton Friedman a piac szabályaira esküdött. Szerinte az államnak nem szükséges beavatkoznia, a piac megoldja a területi egyenlőtlenség problémáját. Friedman nézete szerint a szabadpiaci árrendszernek nincsenek olyan alapvető hibái, amelyek munkanélküliséget teremtenének. Kidolgozta a munkanélküliség természetes rátájának elméletét, amely szerint a munkanélküliség lényegében véve önkéntes, és ez alakítja a munkanélküliség természetes rátáját. Azért alakul ki a munkanélküliség, mert a munkavállalók egy része nem hajlandó a felajánlott munkabérért dolgozni. Mindezekből az következik, hogy elvileg létezik egy egyensúlyi bérszínvonal, amely mellett biztosítható a teljes foglalkoztatottság. A béreket arra az egyensúlyi szintre kell csökkenteni, amely mellett a teljes foglalkoztatottság megvalósulhat. Azaz a munkabéreknek lefelé is rugalmasnak kell lenniük.

Jelentősek a globalizáció munkaerőpiacot érintő hatásai is, a termelés kihelyezése miatt az érintett országokban növekszik a munkanélküliség, és hasonló következménnyel jár az innováció, az automatizáció és a magas fokú gépesítettség a termelő szektorban. A kormányzati beavatkozás fontos és nélkülözhetetlen a munkanélküliség kezelésében (Mouhammed 2011).

Az eddigi magyarországi beavatkozások mindegyik röviden bemutatott elmélethez kapcsolhatók egy kicsit. A regionális politikában az infrastruktúra fejlesztése a térségben működő cégek versenyhátrányát mérsékeli azzal, hogy költségstruktúrájukat befolyásolja, ezzel a keynes-i gondolatmenetet követve, bővítheti a belső piacot, ami további vállalkozások indítását alapozhatja meg. A foglalkoztatáspolitika célja a munkanélkülivé váltak szociális megsegítése, a tűzoltás mellett ugyanakkor a helyzetből való kilábalás technikáira már kevesebb figyelem jut. A munkanélküliek tömegeinek bevonása a régiók gazdasági dinamizálásába pedig egyáltalán nem volt jellemző (Köllő 2005; Boda 2007; G. Fekete, Lipták 2014).

\section{A közfoglalkoztatás tartalmának változása és a közfoglalkoztatás hatásai}

A 1993. évi III. törvény szerint a közfoglalkoztatás formái közé tartozott a közhasznú munkavégzés, a közmunkaprogram és a közcélú foglalkoztatás keretében történő munkavégzés. Közhasznú munkavégzés (bevezetése: 1987) keretében a lakosságot, illetve a települést érintő közfeladatok ellátását valósították meg, amely lehetett kötelező vagy az önkormányzat által önként vállalt feladat is. A feladatot végző álláskereső foglalkoztatásából eredő közvetlen költségek támogatása a munkaügyi kirendeltséghez benyújtott kérelem alapján történhetett. A 
közhasznú munkavégzés nemzetközileg elfogadott definíciója szerint: „a közhasznú foglalkoztatás, mint a munkanélküliség alternatívája, az állástalanok munkaerő-piaci reintegrációját átmenetileg biztosító kényszermegoldás, amely a piaci erők természetes munkahelyteremtő képességének az elégtelensége miatt, a versenyszféra müködését nem zavaró módon hoz létre közpénzek támogatásával pótlólagos munkaalkalmat a közületi és non-profit szektor közérdekű feladatainak ellátására. Résztvevői csak állami munkaügyi szervezetek által kiközvetített munkanélküliek lehetnek" (Frey 1993, 30.). A rendszerváltást követően Magyarországon elsőként ez a típus jelent meg a közfoglalkoztatáson belül.

A közmunkaprogram (bevezetése: 1996) a tartós álláskeresők és az álláskeresési ellátásból már kiszorult aktív korú személyek átmeneti foglalkoztatása munkaviszony keretében, olyan munkakörben, ami települési, közösségi célokat valósít meg. Az országos kiterjedésü közmunkaprogramokban többnyire szezonális, nehéz fizikai munkákat végeztek, úgymint az ár- és belvízvédelmi rendszerek helyreállítása és fenntartása, a közúthálózat karbantartása, vagy környezetvédelmi feladatok ellátása (Bördős 2014).

A közcélú munka (bevezetése: 1997) azon állami vagy helyi önkormányzat által kötelezően ellátandó, illetve önként vállalt feladat végrehajtására irányuló tevékenység, amelynek megszervezéséről, teljesítéséről a helyi önkormányzat gondoskodik. A közcélú foglalkoztatás rendszere a 2000-es évektől kezdett átalakulni (Ördögh 2002), s ennek célja a „segély helyett munka”, azaz a workfare elvének megvalósítása, valamint a feketemunka visszaszorítása volt (Csoba 2010a; Váradi 2016). A változások kiindulópontja az volt, hogy a munkanélküliség fó okaként a munkakínálati oldalon megfigyelhető problémákat jelölték meg, vagyis azt feltételezték, hogy a munka nélkül maradottaknak előnyösebb segélyből élni és illegálisan, „feketén” dolgozni, mint állandó munkát vállalni, s így a munkanélküliséghez kapcsolódó támogatások csökkentésével, a feltételek szigorításával munkára lehet késztetni, a közfoglalkoztatással pedig munkára lehet nevelni a munkanélkülieket (Cseres-Gergely, Molnár 2014). A segélyezettek számára az együttműködési kötelezettség tehát már nem az önkormányzati szabályozás függvénye volt, hanem törvényi erejü követelmény (Csoba 2010a), ami a 2008-ban bevezetett „Út a munkához” (UMA) programban jelent meg. A program keretében az önkormányzatok a munkaképes, munkát kereső, de nem találó személyek számára évi minimum 90 nap közfoglalkoztatásban való részvételt biztosítottak, maximum a minimálbérnek megfelelő díjazás mellett. A program céljai között szerepelt az érintett csoportok visszavezetése a munkaerőpiacra, a munkahelyteremtést támogató projektek bővítése, és ezzel egy időben a feketemunka visszaszorítása (G. Fekete 2014). Az „Út a munkához” program főleg a 2008. évi gazdasági világválság negatív hatásaira igyekezett gyors választ és reakciót adni, ezáltal a magas munkanélküliséget visszaszorítani (Bass 2010). A válságkezelésen és a munkaerőpiaci reintegráción túl a társadalmi elégedetlenség mérséklése is célja volt - ezt Zolnay (2013) szegénységellenes fordulatnak nevezte -, hiszen ha egyre többen dolgoznak, egyre többen járulnak hozzá a közös teherviseléshez. 
Az „Út a munkához” program mindössze két évig, 2011-ig működött. A program előnyei - erőteljesebb ösztönzés a munkavállalásra, munkaszocializációs hatás és területi célzás - mellett az elemzők több hátrányára is rámutattak. A legfontosabbakat említve: a közfoglalkoztatás rövid (három hónapos) ideje nem volt elég a munkaerőpiaci reintegrációs hatások elérésére; nem csökkentek a programba bekapcsolódó települések közötti egyenlőtlenségek; a tartós munkanélküliek többsége bezáródott a segélyezési, szegénységi csapdába (Bass 2010; Csoba 2010a; G. Fekete, Lipták 2010; Váradi 2010; Virág, Zolnay 2010).

2011. január elsejétől a korábbi közfoglalkoztatási formákat felváltotta az „egységes közfoglalkoztatás rendszere", vagyis a Nemzeti Közfoglalkoztatási Program (Bagó 2013; Koós 2016). Módosultak a finanszírozási keretek és lehetőségek: megnőttek a közfoglalkoztatási célokra rendelkezésre álló források, és a költségvetési keret felülről nyitottá vált. Az önkormányzatok fajlagosan sokkal nagyobb támogatást kaptak a közfoglalkoztatásra, mint a segélyekre (Novoszáth 2018). Az újítások egyik célja az volt, hogy a közfoglalkoztatási rendszer egységes jogi szabályozási keretet kapjon, amely segít a munkaképes, álláskereső személyeknek abban, hogy újra munkájuk legyen, és így visszaléphessenek a munkaerőpiacra (Pődör 2016; Mélypataki 2017). Vagyis a cél továbbra is a munkaerőpiaci reintegráció maradt, s az, hogy a gyakran stigmatizált tartós közfoglalkoztatás (G. Fekete 2014) betöltse tranzitfoglalkoztatási szerepét.

A nemzeti közfoglalkoztatás új rendszerében nemcsak az önkormányzatok lehetnek közfoglalkoztatók, hanem a vízügyi igazgatóságok, a nemzeti parkok, a közhasznú jogállású szervezetek, a szociális szövetkezetek, az erdőgazdálkodók, a civil szervezetek, az egyházi jogi személyek, valamint a vasúti pályahálózatmüködtető szervezet is (Szabó 2013). Változást jelent a korábbi gyakorlathoz képest, hogy az új rendszerben megszűnt a 35 év alatti és legfeljebb alapfokú iskolai végzettséggel rendelkező munkanélküliek kötelező képzése (Pirisi 2018).

A 375/2010 (XII. 31) Korm. rendelet az alábbi közfoglalkoztatási támogatási formákat különítette el: rövid időtartamú közfoglalkoztatás (amelyet 2013-ban megszüntettek az alacsony érdeklődés miatt), hosszabb időtartamú közfoglalkoztatás (maximum 12 hónapra), országos közfoglalkoztatási program és a START Közmunka mintaprogramok vagy startmunka-mintaprogramok (Pirisi 2018; Novoszáth 2018). A megyében 2015-ben és 2016-ban volt a legmagasabb a közfoglalkoztatottak létszáma, azóta folyamatosan csökken (1. ábra).

A startmunka-program a munkaerőpiaci szempontból leginkább kedvezőtlen helyzetben lévő, főként vidéki településeken jellemző (13 megyében, 28 kistérségben, 493 településen összesen 980 mintaprogram indult el). 2012-ben további 66 hátrányos helyzetủ térségben indítottak el kistérségi START programot. Az érintett települések száma 1500 fölé emelkedett. A kistérségi, majd járási startmunka-mintaprogramban az értékteremtő (mezőgazdasági terményeket elóállító, néha feldolgozó) mezőgazdasági program a leggyakoribb, amely lehetővé tette gépek és eszközök beszerzését is. A járási startmunka-mintaprogram 
1. ábra: A közfoglalkoztatottak létszámának alakulása Borsod-Abaúj-Zemplén megyében The number of public works participants in Borsod-Abaúj-Zemplén county

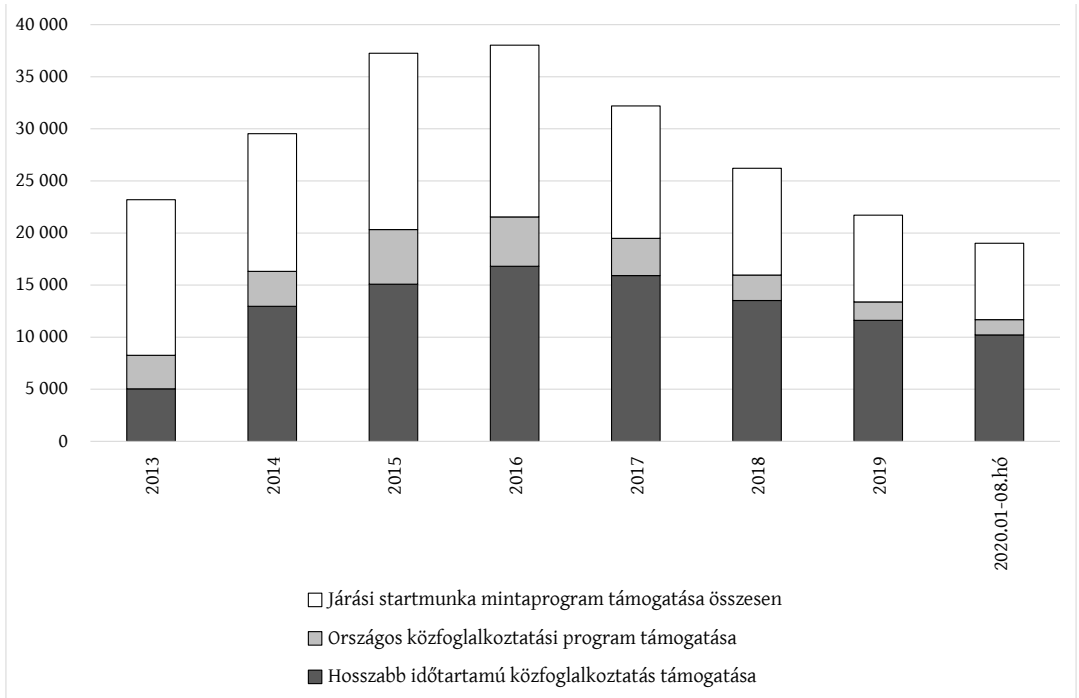

Forrás: http://kozfoglalkoztatas.bm.hu/ alapján saját szerkesztés

mérsékelte a közfoglalkoztatási források elosztásában mutatkozó egyenlőtlenségeket, és a periferikus térségek települései számára forrásbővülést eredményezett (Váradi 2016). A mintaprogramok támogatásának egyik feltétele volt, hogy a tevékenység igazodjon a helyi igényekhez, s el kellett kerülni azt, hogy a program versenytársként jelenjen meg a hasonló profilú vállalkozások piacán. A legfontosabb cél a helyi munkalehetőségek bővítése, illetve kedvező közösségi hatások elérése volt (G. Fekete, Lipták 2014).

A munkanélküliség és a szegénység problémáját a magyar kormány a közfoglalkoztatás kiterjesztésével akarta megoldani, így a közfoglalkoztatás egyszerre tölt be szociális, foglalkoztatási és politikai funkciókat (Váradi 2015). A közfoglalkoztatás rendszeres jövedelmet jelent az érintett családokban, ami tervezhetőbbé, biztonságosabbá teszi az életet, de a szegénységből nem vezet ki. Nem egy esetben a megnövekedett helyi jövedelem hatására a településen is növekszik a vásárlóerő; a közfoglalkoztatás keretében végzett infrastruktúrafejlesztés pedig akár a helyi idegenforgalomra is hatással lehet. A startmunka program hozzájárult a települések önellátó kapacitásainak bővítéséhez, a helyben termelt élelmiszereket jellemzően a helyi intézményi étkeztetésben használják fel. Mivel a „segélyért munka” elve jószerivel teljes társadalmi támogatottságot élvez, a közfoglalkoztatás kiterjesztése mérsékelte a lokális társadalmi feszültségeket is. Kisebb településeken, aprófalvakban jellemző, hogy mindenkit igyekeznek bevonni a közfoglalkoztatásba, akár rövidebb időre is (lásd mindehhez Asztalos-Morell 2014; Szőke 2015; Váradi 2016; Keller, Rácz, Váradi 2016; Koltai et al. 2018; Kovai 2019). G. Fekete szerint a közfoglalkozatás 
hasznos lehet mind az egyénnek, mind a közösségnek. Egyrészről, jó szervezés mellett, szépül, épül, egészségesebbé és élhetőbbé válik a település, stabil marad a munkamorál. Másrészről a foglalkoztatottak haszna, hogy az elvégzett munkáért a segélyeknél magasabb összegű munkabért kapnak, példát mutatnak gyermekeiknek, a társadalom hasznos tagjának érezhetik magukat, ezáltal nő az önbecsülésük (G. Fekete, Lipták 2014).

A kutatók között többnyire egyetértés van a közfoglalkoztatás negatív hatásait illetően. Többen is említik a beragadási hatást (azaz a közfoglalkoztatás ideje alatt a részvevőknek nincs idejük az álláskeresésre, és így tartósan közfoglalkoztatottak maradnak); a munkahelytorzító hatást (gyakran még azok is inkább a közfoglalkoztatásban vállalnak munkát, akik egyébként a képességeik és lehetőségeik alapján el tudnának helyezkedni az elsődleges munkaerőpiacon) (lásd Kálmán 2015; Koós 2016; Váradi 2016). Továbbá a kiszorítási hatással (a közfoglalkoztatási programok elszívják a munkaerőt az elsődleges munkaerőpiacról), emellett a helyettesítési hatással (a korábban nem közfoglalkoztatottak által betöltött munkaköröket is a közfoglalkoztatottak töltik be) is számolni kell. A közfoglalkoztatásnak számos előnye és hátránya van tehát, de a perifériákon szinte nincs más munkalehetőség.

A probléma kezelésének újszerüsége abban állhat, hogy az alacsony gazdasági teljesítmény és magas munkanélküliség problémáját együttesen kezeljük, és egymást erősítő regionális politikai és foglalkoztatáspolitikai beavatkozásokat tartunk szükségesnek. A kiinduló elv az lehet, hogy munkahelyet teremteni önmagában a foglalkoztatás kedvéért nem elég, a foglalkoztatási törekvések mögött valamilyen értelmes gazdasági tevékenységnek és teljesítménynek kell állnia. Jelenleg a probléma kezelési módjának tekinthető élénkülő nonprofit aktivitás (Csoba 2020) és a helyi önkormányzatokhoz kapcsolódó közfoglalkoztatás jelölik ki az útkeresés irányait. A regionális gazdaság fejlesztése és a foglalkoztatás együttes követelményére alapozva felállíthatók a területi fejlődést is előbbre vivő foglalkoztatási megoldási alternatívákkal szembeni elvárások. Ezek az alábbiak: regionális méretekben érzékelhető lépték, azaz legalább a munkanélküliek 20\%-a számára nyújtson megoldást; a tartós foglalkoztatáshoz vigyen közelebb az elsődleges munkaerőpiacra való bejutással; teremtsen értéket; a létrehozott termék, szolgáltatás valós igényeket elégítsen ki; javítsa a munkavállalók kompetenciáit; növelje a szellemi tőkét; szocializáljon a felelősségteljes munkavégzésre. Mindezek együttesen biztosan meghaladják a jelenleg a közfoglalkoztatásban nagy arányban megjelenő helyi önkormányzatok kompetenciáit, mivel számos más feladattal is meg kell küzdeniük, és nincs kapacitásuk a foglalkoztatással járó gazdaságfejlesztési feladatok menedzselésére (G. Fekete, Lipták 2010). 


\section{A közfoglalkoztatás jellemzői a Borsod-Abaúj-Zemplén megye településein}

G. Fekete Éva kutatási terepe főleg az Észak-magyarországi régió, azon belül is a szívéhez közeli Cserehát és a csereháti aprófalvak voltak. Az Észak-magyarországi régióban a 2000-es évektől kezdődően az egymástól elszigetelten, de egyszerre futó regionális politikai és foglalkoztatáspolitikai kezelési mód nem váltotta be a reményeket. Nemhogy csökkent volna, de a növekvő ráfordítások mellett is tovább növekedett a más régióktól való lemaradás (Rechnitzer et al. 2004; Lengyel, Fenyővári 2010). A vállalkozások foglalkoztató képességét sem sikerült javítani. A foglalkoztatottsági ráta az Észak-magyarországi régióban az országos átlag alá csökkent, és a roma népességcsoportban a 15\%-ot sem érte el. A munkaképes munkanélküliek segélyezése egyre nagyobb társadalmi elégedetlenséget váltott ki.

Ahogy a 2. ábra mutatja, a rendszerváltás utáni nagyon magas munkanélküliségi létszám a 2000-es évek elejére mérséklődött, majd 2011 után előbb kismértékü, majd jelentős csökkenés vette kezdetét a megyében. Ezt követően is folyamatos volt a csökkenés: 2017-ben már csak 16 400, 2019-ben pedig 12800 fö volt munkanélküli. A munkanélküliek számának ilyen feltűnő csökkenése a közfoglalkoztatási rendszer kiterjesztésével, a külföldi munkavállalással, valamint a válság utáni kilábalás idején a közfoglalkoztatásból való kiáramlással

2. ábra: A munkanélküliek létszámának alakulása Borsod-Abaúj-Zemplén megyében 1992 és 2019 között

The number of unemployed in Borsod-Abaúj-Zemplén county between 1992 and 2019

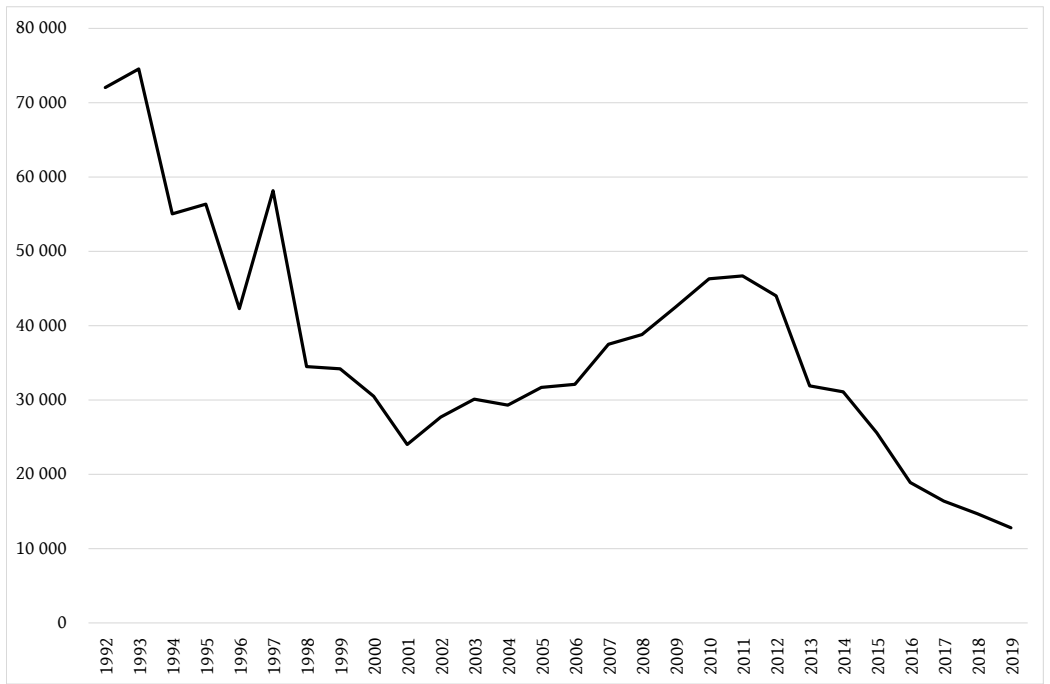

Forrás: Saját szerkesztés KSH területi statisztikai adatok alapján 
magyarázható (Koltai et al. 2018). A 2020-as adatok a COVID-19 járvány negatív hatásai miatt sokkal magasabbak lesznek az előző évekhez képest.

\section{A közfoglalkoztatás kérdőives felméréseinek eredményei}

G. Fekete Éva szakmai vezetésével 2010-ben az „Önkormányzatok és civil szervezetek helyi foglalkoztatási kapacitásainak növelési lehetöségei" kutatás keretében kérdőíves felmérést végeztünk az Észak-magyarországi és az Észak-alföldi régióban, akkor összesen 100 település adataival dolgoztunk, amelyből 56 település Borsod-Abaúj-Zemplén megyében található. A vizsgált települések 40\%-ában már 1997 előtt is szerveztek közfoglalkoztatást, ám ennél valamivel több esetben csak 2000 után indult el a program. A kutatás a munka világából kiszorultak foglalkoztathatóságát és a települési szintű foglalkoztathatósági kapacitásokat tárta fel. A közfoglalkoztatást szervező önkormányzatok látókörébe akkor még kis számban kerültek a foglalkoztatási feladatok elvégzésére is alkalmas civil szervezetek. A kérdőíves felmérésen túl települési szintű esettanulmányok is készültek, ennek keretén belül a meglévő civil szervezetek foglalkoztatási kapacitásait is elemeztük. Végül négy helyi foglalkoztatási modellt sikerült azonosítanunk:

1. Viszonylag erős foglalkoztató kapacitás az elsődleges munkaerőpiacon és ezt kiegészítő szerényebb közfoglalkoztatás (minél nagyobb volt egy település, annál valószínübb volt ez a modell).

2. Magas vagy közepes kapacitás az elsődleges munkaerőpiacon és a közfoglalkoztatásban egyaránt. A kisebb népességszámú, de nagyobb munkanélküliségi rátával rendelkező településekre volt jellemző.

3. Gyenge foglalkoztató kapacitás az elsődleges munkaerőpiacon és erős, vagy közepes közfoglalkoztatás, a magas munkanélküliséggel élő, főként kistelepülésekre volt jellemző.

4. Gyenge foglalkoztató kapacitás az elsődleges munkaerőpiacon és gyenge közfoglalkoztatási kapacitás, a közepes méretü és nagyobb munkanélküliséggel rendelkező településeken volt ez gyakori (G. Fekete et al. 2011).

Úgy döntöttem, hogy tíz év elteltével érdemes lenne megnézni, hogy milyen változások mentek végbe a településeken a közfoglalkoztatás területén. Ezúttal csak Borsod-Abaúj-Zemplén megye önkormányzatait kerestem meg, és kértem a segítségüket a kérdőíves felmérésben való részvételre. (Ugyanazt a kérdőívet használtam, mint a tíz évvel korábbi kutatásban. A kérdőívet eljuttattam a megyében található összes település önkormányzatának, de csak 43 településről érkezett értékelhető válasz.) A válaszadók között többnyire aprófalvakat, kisebb községeket találunk, de néhány nagyváros is kitöltötte a kérdőívet. A települési kategóriáknál a G. Fekete Éva által alkalmazott beosztást használtam én is az összehasonlíthatóság kedvéért (3. ábra, 1. táblázat).

Sajnos nem minden esetben sikerült ugyanazokat a településeket válaszra bírnom, mivel azonban nem települési, hanem megyei szintű összehasonlításra 
3. ábra: A 2010. évi és 2020. évi kérdőíves felmérésben részt vett települések a településméret alapján kategorizálva

Municipalities participating in the 2010 and 2020 surveys by settlement size

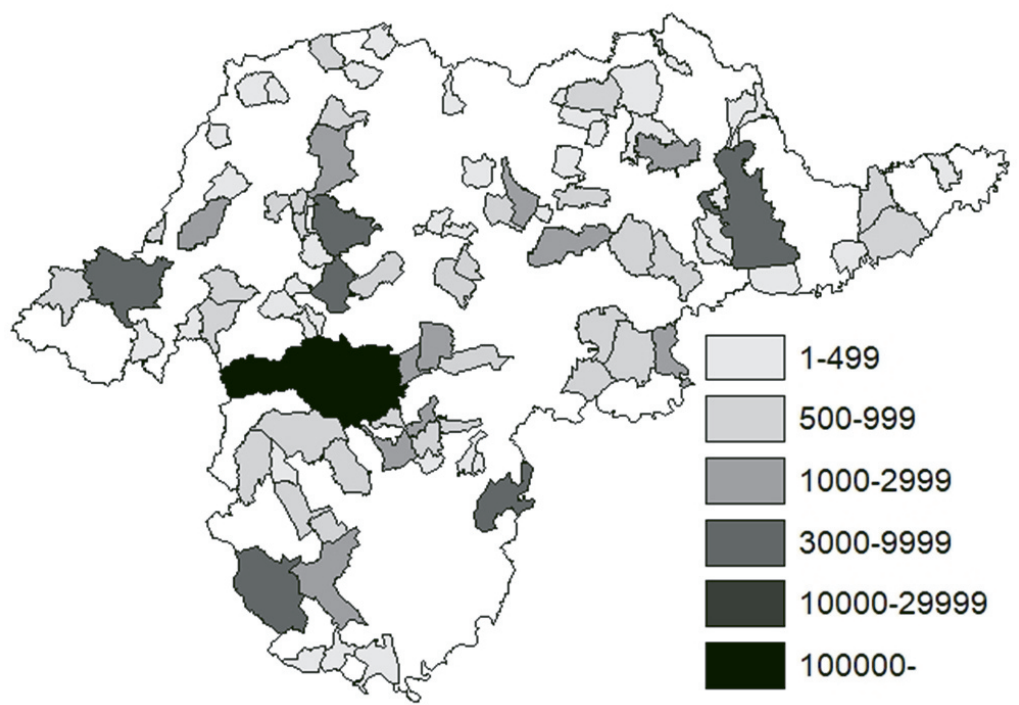

Forrás: Saját szerkesztés KSH adatok alapján

törekedtem, ettől eltekintettem, és minden beérkezett választ feldolgoztam az adatok tisztítása után. A kis elemszámú minta miatt az eredményeket fenntartásokkal kell kezelni, ugyanakkor a térség főbb közfoglalkoztatási mintázata jól kirajzolódik.

A 2010. évi minta a térség településhálózati szerkezetéhez képest a nagyobb települések irányába torzít (1. táblázat). Az aprófalvakból létszámarányukhoz képest csak feleannyit, a közepes falvakból létszámarányuknak megfelelő számú és a nagyobb településekből létszámarányuk kétszeresének megfelelő számú települést válogattunk be a lekérdezés mintájába. A 2020. évi lekérdezés viszont az aprófalvak és kitelepülések irányába torzít.

A foglalkoztathatóság megítélése a településméret szerint némiképp változik (2. táblázat). (A kérdőívben szereplő kérdés: „Milyen a munkanélküliek

1. táblázat: A kérdőíves felmérésbe bevont települések száma (db)

a 2019. évi lakosságszám alapján

Number of settlements participating in the surveys by 2019 population size

\begin{tabular}{cccccccc}
$1-499$ & $500-999$ & $\begin{array}{r}1000- \\
2999\end{array}$ & $\begin{array}{c}3000- \\
9999\end{array}$ & $\begin{array}{c}10000- \\
29999\end{array}$ & $\begin{array}{c}30000- \\
99999\end{array}$ & $100000-$ & Osszeser \\
10 & 12 & 20 & 7 & 6 & 0 & 1 & 56 \\
12 & 9 & 13 & 7 & 2 & 0 & 0 & 43 \\
\hline
\end{tabular}


munkavégző képessége az Ön településén? Értékelje 1-től 4-ig, ahol 1: leggyengébb, 4: legerősebb.") A leginkább szembetűnő a nagyvárosok kritikusabb véleménye: a foglalkoztathatóság mértékét minden szempont alapján alacsonyabbnak, a megbízhatóság és hozzáállás hiányát pedig súlyosabbnak ítélték meg 2010-ben, mint a kisebb településeken. Ugyanakkor a munkaerő fejleszthetőségében való bizalmuk erősebbnek bizonyult. A kisebb településeken minden szempont alapján magasabb arányban tartották foglalkoztathatónak a munkanélkülieket. Különösen az egészségi állapotot tekintve optimistábbak. A munkaerő hozzáállásának, megbízhatóságának megítélése a 3-10 ezer lakos közötti településeken nagyobbnak tekinthető. 2010-ben a munkatapasztalatot $(3,18)$ követően a munkához való hozzáállás $(2,68)$ kapta a legmagasabb pontot. 2020-ra ez a vélemény annyiban változott, hogy összességében az egészségi állapot $(2,51)$, majd a megbízhatóság kapta a legmagasabb átlagos pontot $(2,30)$, vagyis tíz év alatt átrendeződött a munkanélküliek foglalkoztathatóságának értékelése. A friss felmérésben sokkal alacsonyabb pontokat adtak. Az aprófalvak és a nagyobb települések esetében minden szempontot illetően más értékrend és fontossági sorrend alakult ki.

2. táblázat: A válaszadó települések átlagos pontértékei a munkanélküliek

foglalkoztathatóságára vonatkozóan településméret szerint

Average score values of responding settlements regarding the employability of the unemployed by settlement size

\begin{tabular}{|c|c|c|c|c|c|}
\hline Településméret & $\begin{array}{c}\text { Egészségi } \\
\text { állapot }\end{array}$ & $\begin{array}{c}\text { Iskolai } \\
\text { végzettség }\end{array}$ & $\begin{array}{l}\text { Munka- } \\
\text { tapasztalat }\end{array}$ & Megbizhatóság & $\begin{array}{c}\text { Munkához való } \\
\text { hozzáállás }\end{array}$ \\
\hline \multicolumn{6}{|l|}{ 2010. évi felmérés } \\
\hline $10-499$ & 2,10 & 2,00 & 2,60 & 2,20 & 2,90 \\
\hline 500-999 & 2,17 & 2,42 & 2,58 & 2,25 & 2,58 \\
\hline $1000-2999$ & 2,20 & 2,50 & 2,45 & 2,30 & 2,55 \\
\hline $3000-9999$ & 2,00 & 2,71 & 2,43 & 2,14 & 2,71 \\
\hline $10000-29999$ & 2,17 & 3,00 & 2,67 & 2,33 & 2,67 \\
\hline 30 000-999999 & n. a. & n. a. & n. a. & n. a. & n. a. \\
\hline $100000-$ & 4,00 & 2,00 & 3,00 & 3,00 & 4,00 \\
\hline Átlag & 2,18 & 2,46 & 3,18 & 2,27 & 2,68 \\
\hline \multicolumn{6}{|l|}{ 2020. évi felmérés } \\
\hline $10-499$ & 2,50 & 2,25 & 2,17 & 2,42 & 2,50 \\
\hline 500-999 & 2,78 & 1,67 & 2,11 & 2,33 & 2,33 \\
\hline $1000-2999$ & 2,31 & 2,00 & 2,00 & 2,08 & 1,85 \\
\hline $3000-9999$ & 2,43 & 1,86 & 1,86 & 2,29 & 2,00 \\
\hline $10000-29999$ & 3,00 & 1,50 & 2,50 & 3,00 & 3,50 \\
\hline 30 000-999999 & n. a. & n. a. & n. a. & n. a. & n. a. \\
\hline $100000-$ & n. a. & n. a. & n. a. & n. a. & n. a. \\
\hline Átlag & 2,51 & 1,95 & 2,07 & 2,30 & 2,23 \\
\hline
\end{tabular}


A közfoglalkoztatás a megyében annak elindulásától jelen van. (A kérdőívben szereplő kérdés: „Mióta működik közfoglalkoztatás a településen?”) A vizsgált települések 54\%-ban már 1997 előtt is szerveztek közfoglalkoztatást, ám ennél valamivel több esetben csak a 2000 utáni évektől emlékeznek a közfoglalkoztatás indulására. Sem a településméret, sem a települési fejlettség nem befolyásolta a helyi közfoglalkoztatás indulásának időpontját, ám a kisebb és fejletlenebb, valamint a nagyobb és fejlettebb településeken inkább jellemző a későbbi kezdés. A közepes méretű és fejlettségü településeken hamarabb indították a közfoglalkoztatási programokat. A 2010. évi felmérésben részt vett települések jellemzően 1997 előtt indították a közfoglalkoztatást, míg a 2020. évi felmérésben részt vettek 2000 után indították nagyobb arányban. Az aprófalvak és 3000 fö alatti települések esetében a 2008. évi gazdasági válság után növekedett meg a közfoglalkoztatási programokba való belépés kezdő éve. A közfoglalkoztatási rendszer változása tette lehetővé, sőt támogatta a periférikus térségekben, az aprófalvakban a szélesebb körű részvételt. Ezekben a térségekben a helyi fejlesztések sokszor kizárólagos forrása a közfoglalkoztatás, különösen igaz ez a startmunka-mintaprogram településeire, ahol a helyi fejlesztésekhez olcsó és biztos munkaerő valamint viszonylag bőséges támogatás áll rendelkezésre (Váradi 2016).

A közfoglalkoztatás kiterjedtsége a településméret és a települési fejlettség szerint is egyértelmű lejtőt rajzol ki (3. táblázat). (Kérdőívben szereplő kérdés: „Átlagosan évente hány embert foglalkoztattak eddig?") A legkisebb településeken akár a népesség több mint 10\%-a is érintett lehet a közfoglalkoztatásban. 2010-ben a települések mérete alapján az aprófalvak 40\%-a a népességen belül 10-20\% közötti közfoglalkoztatottal rendelkezett: például Háromhután 30,3\%, Regécen 14\%, Füzérkomlóson 13,4\%, Lácacsékén $11,7 \%$ volt a közfoglalkoztatottak aránya a népességen belül. Ezzel szemben a nagyobb és fejlettebb települések népességének csak alig 1\%-a volt érintett. A 3000 fó alatti településekre volt inkább jellemző, hogy a közfoglalkoztatottak aránya mindkét vizsgálati évben a népesség 2,5-5,0\%-a között mozgott (Forró 2,4\%, Halmaj 3,1\%, Kisgyőr 3\%, Tibolddaróc 1,7\%). A 3000 fó feletti településeken kisebb mértékben alkalmaznak közfoglalkoztatottakat, volt olyan település, ahol a népesség alig 1\%-a volt érintett 2020-ban (így Tokaj 0,97\%, Nyékládháza 0,5\%). A közfoglalkoztatottak létszáma nagymértékben függ attól, hogy az adott település részt vesz-e a START mintaprogramban, illetve (ezzel összefüggésben) a munkanélküliség mértékétől és a település gazdasági-társadalmi háttérétől.

Megkérdeztük, hogy a felmérést megelőző évben átlagosan hány közfoglalkoztatottat alkalmaztak szellemi és fizikai munkakörben. Az aprófalvakban a tíz évvel korábbi adatokhoz (34,50 fö) képest átlagosan a felére csökkent a közfoglalkoztatottak száma (17,53fö). A 2020. évi felmérés összességében sokkal kevesebb közfoglalkoztatottat mutat, ami a munkaerőhiánynak, a koronavírust megelőző viszonylag stabil munkaerőpiacnak és a javuló gazdasági teljesítménynek köszönhető, továbbá annak, hogy a kormányzat is szorgalmazta a munkaerőpiacra tör- 
3. táblázat: A megkérdezett településeken a közfoglalkoztatásba bevontak népességen belüli aránya (\%) településméret szerint

Proportion of public works participants (\%) within the population in the surveyed

\begin{tabular}{|c|c|c|c|c|c|}
\hline \multirow[b]{2}{*}{ Településméret } & \multirow[b]{2}{*}{$10,01-20,10$} & \multicolumn{2}{|c|}{ settlements by settlement size } & \\
\hline & & $5,01-10,00$ & $2,51-5,00$ & $1,01-2,50$ & $1 \%$ alatt \\
\hline \multicolumn{6}{|c|}{ 2010. évi felmérés } \\
\hline $10-499$ & 40,00 & 10,00 & 50,00 & 0,00 & 0,00 \\
\hline 500-999 & 8,33 & 8,33 & 41,67 & 33,33 & 8,33 \\
\hline $1000-2999$ & 0,00 & 20,00 & 25,00 & 30,00 & 25,00 \\
\hline $3000-9999$ & 0,00 & 0,00 & 42,86 & 57,14 & 0,00 \\
\hline $10000-29999$ & 0,00 & 0,00 & 16,67 & 33,33 & 50,00 \\
\hline $30000-99999$ & 0,00 & 0,00 & 0,00 & 0,00 & 0,00 \\
\hline $100000-$ & 0,00 & 0,00 & 0,00 & 0,00 & 100,00 \\
\hline Végösszeg & 8,93 & 10,71 & 33,93 & 28,57 & 17,86 \\
\hline \multicolumn{6}{|c|}{ 2020. évi felmérés } \\
\hline $10-499$ & 16,67 & 58,33 & 25,00 & 0,00 & 0,00 \\
\hline $500-999$ & 22,22 & 11,11 & 33,33 & 33,33 & 0,00 \\
\hline $1000-2999$ & 15,38 & 46,15 & 38,46 & 0,00 & 0,00 \\
\hline $3000-9999$ & 14,29 & 14,29 & 14,29 & 28,57 & 28,57 \\
\hline $10000-29999$ & 0,00 & 0,00 & 0,00 & 0,00 & 100,00 \\
\hline $30000-99999$ & 0,00 & 0,00 & 0,00 & 0,00 & 0,00 \\
\hline $100000-$ & 0,00 & 0,00 & 0,00 & 0,00 & 0,00 \\
\hline Végösszeg & 16,28 & 34,88 & 27,91 & 11,63 & 9,30 \\
\hline
\end{tabular}

Forrás: Saját szerkesztés

ténő kilépést a közfoglalkoztatotti létszám és a támogatás folyamatos csökkentésével. Jellemzően fizikai munkakörökben alkalmazzák a közfoglalkoztatottakat, elenyésző a szellemi munkakörben dolgozók létszáma.

Megvizsgáltuk a közfoglalkoztatás hosszát (A kérdőívben szereplő kérdés: „Átlagosan hány hónapig alkalmazzák az egyes személyeket közfoglalkoztatottként?") (lásd 4. táblázat). A 2010. évi felmérés idején az aprófalvak 30\%-a 4-6 hónap között vagy 10-12 hónap között alkalmazták a közfoglalkoztatottakat. Tíz évvel később már az összes településkategóriában elmondható, hogy a közfoglalkoztatás átlagos hossza 10-12 hónap közé esik, ami még mindig nem mondható sem hosszúnak, sem tartósnak (Cseres-Gergely, Molnár 2014). Érdemes megemlíteni, hogy a START program keretében az arra érdemeseket gyakran hosszabb ideig, a korábbi 3-5 hónap helyett 10-12 hónapra is foglalkoztatták (lásd még Váradi 2015). Megkérdeztük, hogy tesznek-e a valamit a települések a közfoglalkoztatottak foglalkoztathatóságának javítására. A válaszok szerint a települések több, mint fele támogatja az általános iskola befejezését, és szakmai képzéseket is szerveznek. A települések egyharmada mentális gondozással is segíti a közfoglalkoztatottjait, többnyire ott, ahol magasabb a roma lakosok aránya. 
4. táblázat: A közfoglalkoztatásba bevontak átlagos foglalkoztatási idejének megoszlása (\%) településméret szerint

Distribution of the average employment time of those involved in public works (\%) by settlement size

\begin{tabular}{|c|c|c|c|c|c|c|}
\hline Településméret & < 1 hónap & 1-3 hónap & 4-6 hónap & 7-9 hónap & 10-12 hónap & $>12$ hónap \\
\hline \multicolumn{7}{|l|}{ 2010. évi felmérés } \\
\hline $10-499$ & 0,00 & 0,00 & 30,00 & 10,00 & 30,00 & 30,00 \\
\hline $500-999$ & 0,00 & 0,00 & 8,33 & 25,00 & 50,00 & 16,67 \\
\hline $1000-2999$ & 0,00 & 0,00 & 5,00 & 25,00 & 40,00 & 30,00 \\
\hline $3000-9999$ & 0,00 & 14,29 & 28,57 & 14,29 & 14,29 & 28,57 \\
\hline $10000-29999$ & 0,00 & 0,00 & 16,67 & 0,00 & 50,00 & 33,33 \\
\hline $30000-99999$ & 0,00 & 0,00 & 0,00 & 0,00 & 0,00 & 0,00 \\
\hline $100000-$ & 0,00 & 0,00 & 0,00 & 0,00 & 0,00 & 100,00 \\
\hline Végösszeg & 0,00 & 1,79 & 14,29 & 17,86 & 37,50 & 28,57 \\
\hline \multicolumn{7}{|l|}{ 2020. évi felmérés } \\
\hline $10-499$ & 0,00 & 0,00 & 8,33 & 0,00 & 58,33 & 33,33 \\
\hline $500-999$ & 0,00 & 0,00 & 11,11 & 11,11 & 66,67 & 11,11 \\
\hline $1000-2999$ & 0,00 & 7,69 & 0,00 & 38,46 & 46,15 & 7,69 \\
\hline $3000-9999$ & 0,00 & 0,00 & 0,00 & 14,29 & 57,14 & 28,57 \\
\hline $10000-29999$ & 0,00 & 0,00 & 0,00 & 0,00 & 100,00 & 0,00 \\
\hline $30000-99999$ & 0,00 & 0,00 & 0,00 & 0,00 & 0,00 & 0,00 \\
\hline $100000-$ & 0,00 & 0,00 & 0,00 & 0,00 & 0,00 & 0,00 \\
\hline Végösszeg & 0,00 & 2,33 & 4,65 & 16,28 & 58,14 & 18,60 \\
\hline
\end{tabular}

Forrás: Saját szerkesztés

Feltettük kérdésként, hogy „Van-e tudomásuk arról, hogy a közfoglalkoztatásban részt vevők milyen mértékben jutottak vissza a munkaerőpiacra és tértek vissza a közfoglalkoztatásba az előző években?" Erre a kérdésre 2010-ben az alábbi összesített válaszok születtek: a települések 46,4\%-nak nincs tudomása arról, hogy mekkora arányban jutottak vissza az elsődleges munkaerőpiacra (valószínűleg a közfoglalkoztatásban maradtak az egyének, mivel más lehetőség nincs a kisebb településeken). A települések 21,2\%-a azt mondta, hogy nincs tudomásuk erről, de feltételezik, hogy a korábbi közfoglalkoztatottaknak kevesebb, mint a fele tért csak vissza az elődleges munkaerőpiacra. További 32,1\% úgy válaszolt, hogy van tudomásuk arról, hogy a korábbi közfoglalkoztatottak több, mint 50\%-a visszatért az elsődleges munkaerőpiacra. Meglepő módon az 1000 fö alatti településeken volt a leginkább jellemző az elsődleges munkaerőpiacra való visszatérés. A megismételt felmérésben, tíz évvel később a megkérdezett települések 36,8\%-a mondta azt, hogy a közfoglalkoztatottak valószínűleg tartósan a rendszerben maradnak, $31,6 \%$ szerint kevesebb, mint a felük visszatért az elsődleges munkaerőpiacra, és további 31,6\% úgy tudja, hogy a településen korábban közfoglalkoztatásban dolgozók több, mint fele visszatért az elsődleges munkaerőpiacra. A korábbi közfoglalkoztatottak jellemzően a 3000 fö alatti településeken tértek vissza nagyobb arányban az elsődleges munkaerőpiacra. 
A 2010. évi felmérésben a helyi önkormányzatok az „Út a munkához” program tapasztalatai alapján azonosították a közfoglalkoztatás sikerének feltételeit, a 2020. évi felmérésben pedig ugyazon szempontok alapján értékelték a közfoglalkoztatás sikerességét (4. ábra).

A siker legalapvetőbb feltételének a közfoglalkoztatás szervezésében szerzett tapasztalatot tartották 2010-ben, ami a tíz évvel későbbi felmérésben a második helyre esett vissza. Ezt követi a szociálisan rászorulók aránya és a település intézményi ellátottsága, vagyis az, hogy legyen kikből válogatni (erre utal még a településméret és a romák magas arányának viszonylag hangsúlyosabb kiemelése is), és legyen hol számukra munkát adni. További meghatározó feltétel a település vezetőinek hozzáállása és a munkaügyi szervekkel ápolt intenzív kapcsolat. Az „Út a munkához” program során a helyi foglalkoztatásban kialakult, illetve tovább erősített önkormányzatközpontúságot tükrözi, hogy a megkérdezettek sem a civil szervezetek, sem a vállalkozások aktivitását nem sorolták a közfoglalkoztatási program legfontosabb sikertényezői közé. A 2020-as felmérésben magasabbra értékelték a települések a tényezőket, a fontossági sorrendben azonban csak kismértékű eltérést tapszataltunk. A korábbiakhoz képest hangsúlyosabbá vált a települési önkormányzat és a munkaügyi központ közötti szoros kapcsolat.

Kíváncsiak voltunk arra, hogy az önkormányzatok hogyan értékelik saját közfoglalkoztatási programjuk sikerességét, innovativitását (nyitott kérdésként fogalmaztuk meg a 2020. évi felmérésben). Több település említette, hogy a startmunka-programban mezőgazdasági tevékenységeket végeznek közfoglalkoztatottakkal, ugyanis azon túl, hogy a megtermelt zöldségekkel és gyümölcsökkel

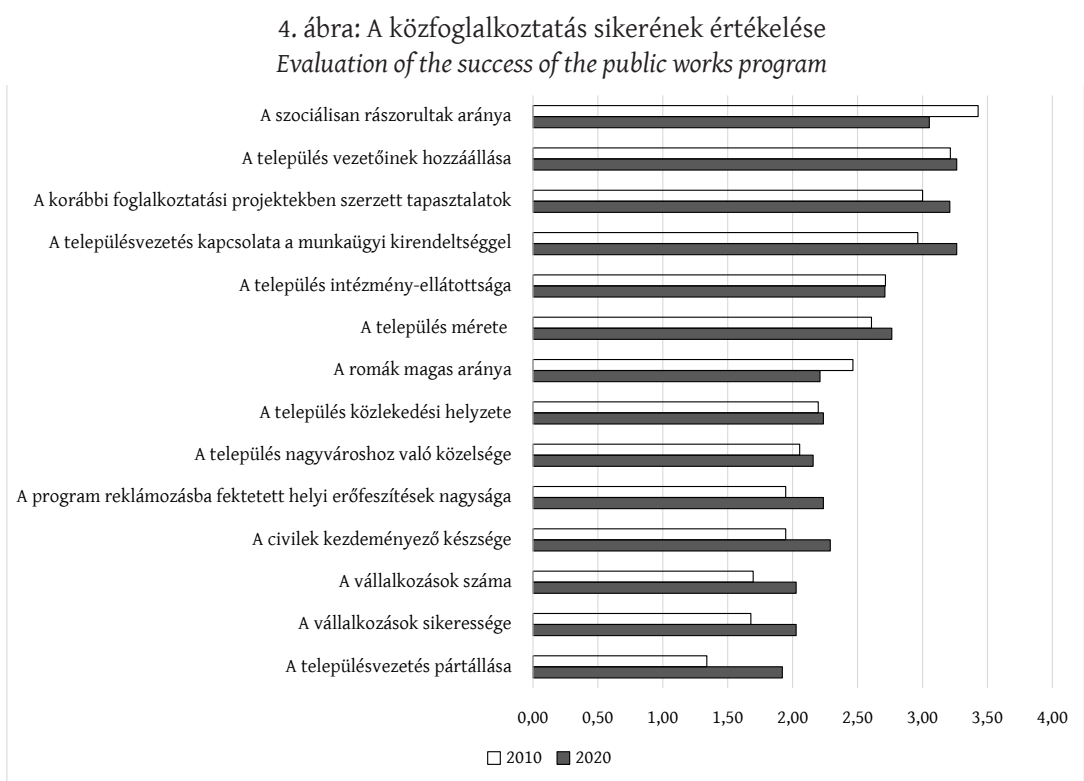

Forrás: Saját szerkesztés 
valódi értékteremtés folyik, a település számára ezek értékesítéséből kevéske bevételre is szert lehet tenni (lásd még Váradi 2015).

Alsóregmec: „Megélhetést biztosit a rászorulók számára, és értékteremtő munkát végeznek.” Girincs: „2012-ben térkőkészitéssel kezdtük meg a munkát, majd utcabútorokat készitünk, és azok folyamatos karbantartását is elvégezzük." A község 2018-ban Start Plusz díjat kapott, és a díjjal járó tízmillió forint értékủ támogatást a program továbbfejlesztésre fordították. 2019-ben is folytatták a szabadidős bútorok készítését, a filagóriákat, padokat, szemeteseket, virágládákat a település közterületein hasznosítják (kozfoglalkoztatas.kormany.hu).

Prügyön a közfoglalkoztatás jól átgondoltan és innovatívan müködik:

„Településünk a közfoglalkoztatás szinte minden lehetőségét kiaknázza. Magas munkanélküliség miatt a rászorultak lehetőséghez jutnak, segélyezés helyett munkabért kapnak, amely jólétet nem biztosít, viszont az alacsony bérezés ösztönző lehet, hogy ne a közmunka jelentsen hosszan tartó megoldást a megélhetésre. Önkormányzat szempontjából költségcsökkentő és értékteremtő tevékenységet végzünk. Mezőgazdasággal is foglalkozunk. Vízelvezetőket saját készítésű mederlappal bélelünk, térkövet gyártunk, melyet parkolók és járdát építésére használunk."

Több településen (Gibárt, Gönc, Mezőzombor, Mikóháza, Sajólád) is elmondták, hogy „megélhetést biztosít a közfoglalkoztatottaknak, és épül, szépül a település.” Néhány faluban a továbblépés felé is elmozdultak és szociális szövetkezetet hoztak létre, ilyen Garadna és Trizs:

„2011. óta folyamatosan két fö programra épülnek a tevékenységeink. Mezögazdasági tevékenységek (növénytermesztés és állattartás), illetve település-karbantartási és - szépítési programjai. 2013-tól szociális szövetkezet működik, ahova azokat az embereket emeljük be, akik önállóan is képesek dolgozni. Ők a húzóerők. A rendszerbe került fiataloknak maximálisan segítünk abban, hogy minél hamarabb kikerüljenek a normál munkaerőpiacra. A fizikailag és pszichésen leépült dolgozóinknak állandó segítséget nyújtunk a mindennapi ügyeik intézésében" (Garadna).

Trizs: „Az elözó években végzett programok után szociális szövetkezetbe sikerült átemelni a tevékenységet és a foglalkoztatottakat. Jelenleg kevés fóvel kis program fut már csak."

A 2020. évi kutatás alatt arra a megállapításra jutottam, hogy a tíz év alatt a közfoglalkoztatás jelentős átalakításával is csak néhány kiemelkedő jó gyakorlat (Hernádszentandrás, Boldva, Trizs) azonosítható, ahol a közfoglalkoztatáson túlmutató szemléletre alapozott társadalmi vállalkozási tevékenység folyik. Az aprófalvakban élők számára a közfoglalkoztatásban való részvétel továbbra is fontos, az alacsony bér ellenére biztos bevételt jelent, és karbantartja a munkavégzéshez szükséges képességeket, készségeket - vagyis munkára szocializál. Összességében, a közfoglalkoztatás vegyes megítélése ellenére a megye települései számára fontos és jó lehetőség, ám nem elég a munkaerőpiaci gondok tartós megoldásához. 


\section{Lehetséges továbblépés: a szociális (szolidáris) gazdaság}

G. Fekete Éva a munkanélküliség megoldását nem a közfoglalkoztatásban látta, hanem a szociális gazdaságban (lásd Csoba 2020). Már 2010 óta foglalkozott a témakör kutatásával és úttörő módon értelmezte a társadalmi gazdaságot; véleménye szerint az üzleti vállalkozások foglalkoztatási potenciálját kompenzáló megoldások megőrzését, ugyanakkor a közfoglalkoztatásból való továbblépés lehetséges módjainak keresését kell szem előtt tartani. A közfoglalkoztatásból vagy az üzleti, vagy a társadalmi gazdaság irányába lehet továbblépni, a vállalkozáshiányos elmaradott térségekben az előbbi nem sok sikerrel kecsegtet. Az utóbbi irány egyik, a kormányzat által előnyben részesített változata a startmunkaprogram szociális szövetkezetté alakítása (G. Fekete, Lipták 2014). Az utóbbi években a kormányzat a közfoglalkoztatásból való kilépést, egyfajta tranzit megoldásként, a szociális szövetkezetek létrehozásával látja megoldhatónak, úgy, hogy kötelezővé teszi az önkormányzati tagságot. Ezeknek a szociális szövetkezeteknek a fenntarthatósága azonban nem biztosított (lásd még Váradi 2016; Csoba 2020).

A munkanélküliség csökkentéséhez a gazdaság szereplőitől - sem a piaci szférától, sem a létszámleépítésre kényszerülő költségvetési szervezetektől - nem várható hathatós segítség. Ezért a nonprofit szervezetekre támaszkodva indokolt számukra a jelenleginél perspektivikusabb megoldásokat keresni. Ennek útja lehet a nonprofit szervezetek foglalkoztatási kezdeményezéseinek támogatása, azaz a munkaerőpiac fóáramán kívüli munkahelyteremtés.

Napjainkban a legelterjedtebb gazdasági modellben három gazdasági szektor létezik egymás mellett. A gazdaságilag aktívként jellemzett első szektorba, a versenyszférába az üzleti vállalkozások, gazdasági társaságok tartoznak, fó céljuk a profitszerzés. Az üzleti tevékenységet nem folytató, ezért gazdaságilag inaktívnak tartott második szektor a költségvetési, illetve közintézményeké, melyek fö feladata a közigazgatás és a jóléti alrendszerek működtetése. A harmadik szektor szervezetei rendkívül változatos képet mutatnak. A szociális vállalkozásokat és a gazdaságilag aktív nonprofit szervezeteket tömörítő szociális gazdaság, a karitatív alapon müködő szervezeteket magába foglaló közösségi gazdaság, és az informális gazdaságot, családi, önellátó tevékenységeket tartalmazó árnyékgazdaság együttesen alkotják a harmadik szektort (G. Fekete et al. 2011).

A piac, az állam és a szociális gazdaság kapcsolatrendszerében az állam gondoskodik a kollektív szükségletekről, a piac az egyéni szükségletekről, a szociális gazdaság pedig a helyi és nem helyi közösségi szükségletekről. A szociális gazdaság lényegét Castel remekül megragadta: „Az erőfeszítés egy szolidáris gazdaság megteremtésére, azaz arra, hogy összekössék a foglalkoztatás és a társadalmi kohézió kérdését, hogy a tevékenységmódokkal egy időben emberek közötti kapcsolatokat is teremtsenek, a lehető legtiszteletreméltóbb" (Castel 1998, 406.).

A szociális gazdaság alapértéke, hogy tevékenységét nem az egyén, hanem a közösség érdekében végzi, igyekszik elősegíteni a területi alapon vagy közös ér- 
dekek mentén szerveződő közösségek kiépülését. A szociális gazdaság területén tevékeny személyek együttműködnek a közös haszon érdekében, a társadalmi vállalkozások a közösséget szolgálják, céljuk nem a profit maximalizálása. A szociális gazdaságban, amelynek célcsoportja általában tartós munkanélküliekből áll, a társadalmi vállalkozások és a szövetkezetek szerepe jelentős, Magyarországon pedig a szociális földprogram is szociális vállalkozásjellegünek tekinthető (G. Fekete, Solymári 2004). Az elmúlt években a megyében is több településen hoztak létre szociális szövetkezetet, amely az önkormányzattól átveszi a közfoglalkoztatás irányítását és szervezését, és a közfoglalkoztatottak által megtermelt termékek értékesítését. Közismert és sikeres példa a hernádszentandrási BioSzentandrás program, az általuk alapított szociális szövetkezet, vagy a boldvai tökmagolaj eloállítására és a közfoglalkoztatás szervezésére létrehozott szociális szövetkezet.

\section{Következtetések}

A 2010-ben végzett kérdőives felméréshez képest a tíz évvel később megismételt vizsgálat ugyan változásokat jelez, de az aprófalvak, periférikus települések helyzete nem javult jelentős mértékben, számukra a legégetőbb problémát továbbra is a munkanélküliség tartósan magas szintje jelenti. Úgy vélem, hogy az aprófalvak munkaerőpiaci problémáinak kezeléséhez szükséges az innovatív, újszerű szemlélet a település vezetése részéről, de ez csak ott valósítható meg, ahol még él fiatal, tenni akaró és cselekvésre képes lakos - legalább a polgármester személyében.

A hazai foglalkoztatáspolitika központjában a klasszikus bérmunka elsőbbsége és a munkahelyek számának bővítése áll. A globális trendek alapján ugyanakkor a bérmunka típusú munkahelyek és a munkaképes népesség száma közötti tartós egyensúlybomlásra kell számítani. A jövőben a munka társadalomszervező funkcióját kellene jobban kihangsúlyozni, és a munkahelyközpontúság felől a munkavagy jövedelemközpontúság felé kéne fordulni. Ez a lemaradó, rurális térségekben, így az Észak-magyarországi régióban sürgető feladat lenne, természetesen azt is figyelembe véve, hogy a rendelkezésre álló munkaerőtartalék csak korlátozottan, illetve csak fejlesztéssel alkalmas a teendők ellátására. A kutatás eredményei alátámasztják G. Fekete Éva megállapítását, miszerint a tartósan magas munkanélküliséggel küzdő, alacsony vállalkozási potenciálú területeken a vegyes foglalkoztatási és jövedelemszerzési modellek felépítése, továbbá a területileg differenciált foglalkoztatáspolitika hozhat megoldást (G. Fekete el al. 2011). Doktori kutatásaim során, még 2013-ban javaslatokat tettem a regionális szintü, területileg differenciált foglalkoztatáspolitika kiépítésére, sajnos az azóta eltelt időszak alatt nem történt elörelépés, a hazai foglalkoztatáspolitika továbbra is országos fókuszú. A jövőben a vegyes gazdaságra és a területileg differenciált foglalkoztatáspolitikára való átállás, az egyes jövedelemszerzési formák összehangolása törvényi, intézményi változásokat, és szemléletváltást igényel a helyi munkaerőpiac minden szereplőjétől. 


\section{Köszönetnyilvánítás}

A kutatást az EFOP-3.6.2-16-2017-00007 azonosító számú, „Az intelligens, fenntartható és inkluzív társadalom fejlesztésének aspektusai: társadalmi, technológiai, innovációs hálózatok a foglalkoztatásban és a digitális gazdaságban" című projekt támogatta. A projekt az Európai Unió támogatásával, az Európai Szociális Alap és Magyarország költségvetése társfinanszírozásában valósul meg.

\section{Irodalom}

Asztalos Morell, I. (2014): Workfare with human face? Metszetek, 4., 3-24. https://metszetek.unideb.$\mathrm{hu} /$ files/201404/_01_asztalos_morell_ildiko.pdf

Bagó J. (2013): A közfoglalkoztatás célja és szabályozása. Munkaügyi Szemle, 1., 4-5.

Bass L. (2010): Az „Út a munkához” program hatása - egy kérdőíves felmérés tapasztalatai. Esély, 1., 46-64.

Boda D. (2007): Az aktív munkaerö-piaci eszközök hatását felmérő monitoring vizsgálatok 2001-2006 közötti idöszakra vonatkozó eredményeinek területi szempontú elemzése. A tanulmány a Szociálpolitikai és Munkaügyi Intézetben, az aktív munkaerő-piaci eszközök müködtetésének tapasztalatait feldolgozó, Frey Mária által vezetett kutatás részeként készült. Budapest, 2007

Bördős K. (2014): A közfoglalkoztatás intézményi környezete - történeti áttekintés. In: Fazekas K. (szerk.): Munkaerőpiaci Tükör 2013. Közelkép, 66-75.

Castel, R. (1996): Work and usefulness to the world. International Labour Review, 6., 615-622.

Cseres-Gergely Zs., Molnár Gy. (2014): Közfoglalkoztatás, segélyezés, elsődleges és másodlagos munkaerőpiac. In: Társadalmi riport. Tárki, 204-224.

Csoba J. (2010a): A közfoglalkoztatás régi-új rendszere. Útközben az „Út a munkához” programban. Esély, 1., 4-24.

Csoba J. (2010b): „Segély helyett közmunka” A közfoglalkoztatás formái és sajátosságai. Szociológiai Szemle, 1., 26-50.

Csoba J. (2020): A szociális gazdaságtól a szolidáris gazdaságig A helyi gazdaságfejlesztési modell átalakulása. Tér és Társadalom, 4., 71-99. https://doi.org/10.17649/TET.34.4.3301

Dahrendorf, R. (1994): A modern társadalmi konfliktus. Gondolat Kiadó, Budapest

Frey M. (1993): A közhasznú foglalkoztatás munkaerő-piaci hatásai. Munkaügyi Szemle, 5., 30-37.

Friedman, M. (1986): Infláció, munkanélküliség, monetarizmus, Közgazdasági és Jogi Könyvkiadó, Budapest

G. Fekete É. (2007): A szolidáris gazdaság elméleti és gyakorlati kérdései. In: Kocziszky Gy. (szerk): VI. Nemzetközi Konferencia A közgazdász képzés megkezdésének 20. évfordulója alkalmából. Miskolci Egyetem Gazdaságtudományi Kar, 79-89.

G. Fekete É. (2011): Foglalkoztatási kutatások 2001-2011. Habilitációs értekezés, Miskolc

G. Fekete É., Dabasi-Halász Zs., Szép T., Lipták K., Osgyáni G., Baksa S., Kispataki Cs. (2011): Önkormányzatok és civil szervezetek helyi foglalkoztatási kapacitásainak növelési lehetőségei. Kutatási zárótanulmány, Miskolc

G. Fekete, É., Lipták, K. (2010): Relationships between public employment and regional development In: Beauclair, A. (ed.): Regional responses and global shifts: actors, institutions and organisations. Annual international conference RSA 2010., 1-11.

G. Fekete É., Lipták K. (2014): Közfoglalkoztatásból szociális szövetkezet? In: Lukovics M., Zuti B. (szerk.) A területi fejlődés dilemmái. Szegedi Tudományegyetem Gazdaságtudományi Kar, Szeged,123-142.

G. Fekete É., Lipták K., Osgyáni G., Simkó J., Siposné Nándori E. (2014): Lokális foglalkoztatáspolitika, a nem piaci foglalkoztatás jellemzői. KJM kutatás zárótanulmánya, Miskolc

G. Fekete É., Solymári G. (2004): A szociális gazdaság kiépítésének esélye és feltételei az Észak-magyarországi régióban. Észak-magyarországi Stratégiai Füzetek, 2., 32-78. 
Kálmán J. (2015): A közfoglalkoztatási programok háttere és nemzetközi tapasztalatai. In: Fazekas K. (szerk.): Munkaerőpiaci tükör, 2014. MTA Közgazdaság- és Regionális Tudományi Kutatóközpont, Közgazdaságtudományi Intézet, Budapest

Keller J., Rácz K., Váradi M. (2016): Közösségi gazdaságfejlesztés a vidéki Magyarországon In: Kovács K. (szerk.): Földből élők Polarizáció a magyar vidéken. Argumentum, Budapest, 207-227.

Keynes, J. M. (1965): A foglalkozás, a kamat és a pénz általános elmélete. Közgazdasági és Jogi Könyvkiadó, Budapest

Koltai L. (2013): A közfoglalkoztatás szerepe válság idején az európai országokban. Munkaügyi Szemle, 1., 27-38.

Koltai L., Bördős K., Csoba J., Herczeg B., Hamza E., Megyesi B., Németh N., Rácz K., Szabó D., Váradi M., Varga E., Virág T. (2018): A közfoglalkoztatás hatása a helyi gazdaságra, helyi társadalomra. Hétfa Kutatóintézet, Budapest http://hetfa.hu/wp-content/uploads/2018/11/BM_k\%C3\%B6zfoglalkoztat\%C3\%A1s_Tanulm\%C3\%A1ny_20180928-merged.pdf (Letöltés: 2020. 03. 20.)

Koltai L., Kulinyi M. (2013): A közfoglalkoztatást szervezők értékei. Esély, 5., 38-67.

Koós B. (2016): Közfoglalkoztatás a mezőgazdaságban. Tér és Társadalom, 3., 40-62. https://doi.org/ 10.17649/TET.30.3.2793

Kovai, C. (2019): Permanent wage labour as a norm. Workfare policy and everyday experiences of precariousness in a small Hungarian former industrial town. Socio.hu Társadalomtudományi Szemle, 7., 143-161. https://doi.org/10.18030/socio.hu.2019en.142

Köllö J. (2005): A magyar foglalkoztatáspolitika átfogó értékelése az Európai Foglalkoztatási Stratégia kontextusában, az elmúlt öt év tapasztalatai alapján. A tanulmány a Foglalkoztatáspolitikai és Munkaügyi Minisztérium által „A magyar foglalkoztatáspolitika átfogó értékelése az Európai Foglalkoztatási Stratégia kontextusában" tárgyában közzétett KÉ-12350/2004 azonosítójú, nyílt közbeszerzési pályázata keretében készült az Magyar Tudományos Akadémia Közgazdaságtudományi Intézetében. Budapest, 2005. augusztus 31.

Lengyel I., Fenyővári Zs. (2010): Az Észak-magyarországi és a Dél-alföldi régiók versenyképességének föbb mutatói. Észak-magyarországi Stratégiai Füzetek, 1., 3-17.

Martin, H.P., Schumann, H. (1998): A globalizáció csapdája. Támadás a demokrácia és a jólét ellen. Perfekt Könyvkiadó, Budapest

Mélypataki G. (2017): A mezőgazdasághoz kapcsoló idényjellegű és közfoglalkoztatási jogviszonyok jellemzői. Agrár-és Környezetjog, 23., 64-90.

Mouhammed, A.H. (2011): Important Theories of Unemployment and Public Policies. Journal of Applied Business and Economics, 5., 100-110.

Musinszki, Z., Süveges, G. (2019): Strategic decision-making supported by traditional financial indicators. Oradea Journal of Budiness and Economics, 1., 29-37.

Novoszáth P. (2018): Az egységes közfoglakoztatási rendszer létrejötte, főbb jellemzői Magyarországon. http://www.kozszov.org.hu/dokumentumok/UMK_2018/kulonszam/04_kozfoglalkoztatasi_rendszer.pdf (Letöltés: 2020. április 15.)

Ördögh S. (2002): Kiszorítja-e a közcélú munka a közhasznú munkát? Munkaügyi Szemle, 1., 12-22.

Pirisi K. (2018): A közmunka szerepe a foglalkoztatáspolitikában, a szegénység és a hajléktalanság kezelésében. Doktori (PhD) értekezés. Szent István Egyetem. Gödöllő

Pődör L. (2016): Gondolatok a közfoglalkoztatási jogviszony munkajogi összefüggéseiról. ART-PR 2005 Kft.

Rechnitzer J., Csizmadia Z., Grosz A. (2004): A magyar városhálózat tudásalapú megújító képessége az ezredfordulón. Tér és Társadalom, 2., 117-156. https://doi.org/10.17649/TET.18.2.949

Szabó A. (2013): A közfoglalkoztatás mint foglalkoztatáspolitikai eszköz. Nagyerdei Almanach, 7., 149-161.

Szőke, A. (2015): A 'Road to Work'? The reworking of deservedness, social citizenship and public work programmes in rural Hungary. Citizenship Studies, 6-7., 734-750. https://doi.org/ 10.1080/13621025.2015.1053790

Váradi M. M. (2010): A közfoglalkoztatás útjai és útvesztői egy aprófalvas kistérségben. Esély, 1., 79-100.

Váradi M. M. (2015): Szegénység, projektek, közpolitikák. Tér és Társadalom, 1., 69-96. https:// doi.org/10.17649/TET.29.1.2678

Váradi M. M. (2016): Értékteremtő közfoglalkoztatás periferikus vidéki terekben. Esély, 1., 30-56. 
Virág T., Zolnay J. (2010): Csapdába került önkormányzatok, csapdában tartott szegények - közfoglalkoztatás a Csereháton. Esély, 1., 119-130.

Vobruba, G. (2000): Alternativen zur Vollbeschäftigung: Die Transformation von Arbeit und Einkommen. Suhrkamp Verlag, Frankfurt am Main

Zolnay J. (2013): Tartós munkapiaci kirekesztés, szegénység és társadalompolitikai válaszok - a kutatás kontextusa. In: Nagy K. (szerk.): A szociális segély csökkentésének hatásai a vidéki Magyarországon, 2012 - interdiszciplináris dokumentáció. Pillangó Kutatás, Pro Cserehát Egyesület, Budapest, $10-23$.

1993. évi III. törvény a szociális igazgatásról és szociális ellátásokról https://net.jogtar.hu/jogszabaly?docid=99300003.tv (Letöltés: 2020.04 .15 .)

2011. évi CVI. törvény a közfoglalkoztatásról és a közfoglalkoztatáshoz kapcsolódó, valamint egyéb törvények módosításáról https://net.jogtar.hu/jogszabaly?docid=a1100106.tv (Letöltés: 2020. 04. 15.)

375/2010. (XII. 31.) Korm. rendelet a közfoglalkoztatáshoz nyújtható támogatásokról https://net.jogtar.hu/jogszabaly?docid=a1000375.kor (Letöltés: 2020. 04. 15.)

Girincs https://kozfoglalkoztatas.kormany.hu/utcabutorok-gyartasa-girincs-kozsegben (Letöltés: 2020. 05. 05.) 